tępicieli (np. święci, rycerze) oraz legend i mitów dotyczące smoków. Na końcu autor przy pomocy środków multimedialnych zaprezentował ciekawe zdjęcia $\mathrm{z}$ różnymi interpretacjami wizerunku smoka oraz miejscami występowania ich w architekturze Krakowa (jest kilkadziesiat). Sa one wykonane np. z kamienia, kute lub odlewane $\mathrm{z}$ metalu, blachy, a do najsłynniejszych pomników należy ten u stóp Wawelu. Również w tej części swoje wystapienie miały studentki Uniwersytetu im. Adama Mickiewicza w Poznaniu: Olga Zagłoba $z$ referatem pt. „Sytuacja kobiet w świetle ustawodawstwa unijnego" i Barbara Laskowska z referatem pt. „Kobieta we współczesnej Polsce”. Wystąpienia te zostały bardzo przychylnie i życzliwie przyjęte, choć uchodziły za kontrowersyjne w swojej treści, a same autorki uznane zostały za feministki, mimo tego, iż nie było to ich zamiarem. Wyciagajac pozytywne wnioski można stwierdzić, że wystapienia te na pewno nie byly nikomu obojętne. Następnie po oficjalnych przemówieniach rozpoczęła się krótka dyskusja, a potem podsumowanie tej części obrad.

Pierwszy dzień konferencji zakończył się uroczystą kolacją. Tutaj też zaproszeni goście mieli okazję i możliwość poznania wszystkich uczestników konferencji oraz wykładowców Akademii Podlaskiej. Można było porozmawiać i zadać pytania dotyczące przedstawionych referatów, wymienić się spostrzeżeniami i uwagami, wyjaśnić wszelkie watpliwości. Z kolei, osoby uzdolnione muzycznie miały możliwość wykazania się swoim „głosem" i talentem, dlatego też nie zabrakło kilku chętnych, którzy zaczęli śpiewać na forum, aby uprzyjemnić pozostałym uczestnikom wieczór. Było też wiele życzliwych dedykacji, często dla nowo poznanych osób - reprezentantów z różnych kól naukowych. Spotkanie trwało do późnych godzin wieczornych.

Drugiego dnia uczestnicy spotkania pojechali na wycieczkę turystyczną do Janowa Podlaskiego. Tu zwiedzano stadninę koni, Park Krajobrazowy i kolegiatę. Ten dzień okazal się nie mniej ciekawy od pierwszego, gdyż wniósł do biografii studentów i pracowników naukowych miłe wspomnienia o pięknych krajobrazach Ziemi Podlaskiej. Dwudniowy zjazd zakończył się po południu wspólnym obiadem. Wybrane referaty zostały opublikowane w materiałach konferencyjnych: red. K. Jankowski, Młodzież akademicka a współczesna nauka, Siedlce 2003.

Mam nadzieję, że kontakty nawiązane w czasie trwania konferencji zaowocują dalszą wymiana myśli i wspólpraca badawcza.

Barbara Laskowska

\title{
Inauguracja roku akademickiego 2004/2005 w Collegium Europaeum Gnesnense - 11 października 2004
}

11 października 2004 roku w Collegium Europaeum Gnesnense odbyło się uroczyste zakończenie pierwszego etapu budowy CEG oraz inauguracja roku akademickiego 2004/2005. Swoja obecnościa uświetnili uroczystość m. in.: JM Rektor UAM prof. dr hab. Stanisław Lorenc, Metropolita Gnieźnieński ks. abp Henryk Muszyński, b. Rektor prof. dr hab. Stefan Jurga, posel Tadeusz Tomaszewski, starosta gnieźnieński Jacek Kowalski, prezydent Gniezna Jaromir Dziel, zastępca prezydenta Gniezna Robert Andrzejewski, Rektor Wyższego Seminarium Duchownego ks. prof. dr hab. Bogdan Czyżewski, Dziekan Wydziału Studiów Edukacyjnych prof. dr hab. Wiesław Ambrozik, Prodziekan WSE prof. dr hab. Dorota Żołądź-Strzelczyk, Prodziekan Wydziału Filologii Polskiej i Klasycznej prof. dr hab. E. Kasprzak.

O godz. 9.00 w hallu CEG, po odśpiewaniu Gaude Mater przez chór Schola Cantora z Kalisza pod batuta prof. dr hab. Andrzeja Ryłko, JM Rektor UAM prof. dr hab. Stanisław Lorenc przywital wszystkich zebranych. W przemówieniu podkreślił nowatorstwo CEG, przedstawil dotychczasowe etapy budowy oraz ich konstruktorów i wykonawców, uwydatnił rolę, jaką w kształtowaniu Collegium 
pełnią Rektor Stefan Jurga oraz Metropolita Gnieźnieński ks. abp Henryk Muszyński. Ten ostatni dokonał poświęcenia budynku. Na zakończenie pierwszej części uroczystości chór zaprezentował program artystyczny.

O godz. 10.30 rozpoczęła się uroczysta inauguracja roku akademickiego 2004/2005. Prorektor UAM prof. dr hab. Bogdan Walczak witając gości, pracowników CEG oraz studentów, podkreślił, jak ważne miejsce zajmuje UAM wśród uniwersytetów polskich. Uwydatnił rolę CEG w integracji kulturowej Europy oraz w kształtowaniu tożsamości narodowej i europejskiej polskiej młodzieży. Witając studentów, docenił ich siłę, zapał oraz entuzjazm młodzieńczy. Przede wszystkim zaakcentował grupę studentów pierwszego roku, kształcących się już w zjednoczonej Europie, którzy w pluralistyczną tożsamość Europy wpisuja swoja tożsamość ojczysta.

Dyrektor naukowy CEG prof. dr hab. Aleksander Mikolajczak zapoznał zebranych z osiagnięciami naukowymi Collegium, tematami konferencji naukowych oraz z podjętymi działaniami na rzecz badań kulturowych korzeni Europy.

Studenci nowego pierwszego roku edukacji europejskiej, europejskiej komunikacji społecznej oraz politologii złożyli ślubowanie oraz odebrali indeksy z rąk Prorektora UAM prof. dr hab. Bogdana Walczaka. Uroczystości towarzyszył chór Schola Cantora z Kalisza.

Prof. dr hab. B. Walczak wręczył medale pamiątkowe CEG Metropolicie Gnieźnieńskiemu ks. abp Henrykowi Muszyńskiemu oraz Rektorowi prof. dr hab. Stefanowi Jurdze za pomoc w realizacji idei powstania Collegium. W podziękowaniach abp $H$. Muszyński podkreślił rolę UAM i CEG w ksztaltowaniu przyszłego oblicza nowej Europy i ojczyzny, którego podstawa jest bogactwo wewnętrzne każdego człowieka. Prof. dr hab. S. Jurga zwrócil uwagę na nowe wyzwania, jakie powinno podjać Collegium: kulturowy dialog młodzieży, wyrażany także przez muzykę, teatr, ideę sportu. Przypomniał również, że CEG jest „dzieckiem” II Historycznego Zjazdu Gnieźnieńskiego.

Wyklad inauguracyjny pt. „Na szlakach renesansowej Europy” wygłosiła prof. dr hab. Dorota Żoładź-Strzelczyk. Prelegentka przedstawila nie tylko kierunki podróży renesansowej młodzieży polskiej, ale także zaprezentowała dodatnie, jak i ujemne skutki peregrynacji w opinii ówczesnych myślicieli.

Na zakończenie uroczystości zostały wręczone wyróżnienia dla sportowców CEG oraz odśpiewano Gaudeamus.

Justyna Gulczyńska

Katarzyna Kabacińska

\section{Powiązania rodzinne wśród twórców polskiej teorii i praktyki edukacyjnej, konferencja naukowa, Gniezno, 28 -30.11.2004 r.}

W dniach 28 - 30 listopada 2004 r. w Collegium Europaeum Gnesnense odbyła się ogólnopolska sesja naukowa poświęcona znaczeniu rodziny w życiu i w działalności twórców koncepcji i ideologii wychowawczych. Przesłankę do zorganizowania konferencji stanowiła problematyka, nie będąca do tej pory przedmiotem głębszych rozważań na żadnym zjeździe historyków wychowania, a pozwalająca poznać uczestnikom, jak dokonywala się transmisja międzypokoleniowa w różnych środowiskach, epokach, w różnych regionach Polski.

Jej organizatorami były dwie placówki uniwersyteckie: Zakład Historii Wychowania Uniwersytetu Adama Mickiewicza w Poznaniu i Zakład Historii Edukacji Uniwersytetu Mikołaja Kopernika w Toruniu, a także dwie młode placówki naukowo-dydaktyczne: Collegium Europaeum Gnesnense i Lużycka Wyższa Szkoła Humanistyczna w Żarach. 